\title{
HUMOR
}

INTERNATIONAL JOURNAL OF HUMOR RESEARCH

EDITOR-IN-CHIEF

Christian F. Hempelmann, Department of Literature and Languages, Texas A\&M University-Commerce, USA E-mail: humorjournal@gmail.com

\section{FOUNDING EDITOR}

Victor Raskin, Purdue University, USA

\section{BOOK REVIEW EDITORS}

(unsolicited book reviews will not be accepted)

Nicholas Holm

Massey University,

n.h.f.holm@massey.ac.nz

Julia Taylor Rayz

Purdue University, USA

E-mail: jtaylor1@purdue.edu

Eric Weitz

Trinity College Dublin

E-mail: weitzer@tcd.ie

\section{EDITORIAL ASSISTANT}

Andrew R. Olah, Western Carolina

University, USA
EXECUTIVE SECRETARY, ISHS

Martin D. Lampert

Holy Names University, USA

\section{EDITORIAL BOARD}

Salvatore Attardo, Texas A\&M

University-Commerce, USA

Delia Chiaro, University of Bologna,

Italy

Wladyslaw Chlopicki, Jagiellonian

University, Poland

Jessica Milner Davis, University of

Sydney, Australia

Thomas E. Ford, Western Carolina

University, USA

Gil Greengross, Aberystwyth University,

UK

Giselinde Kuipers, Katholieke

Universiteit Leuven, Belgium

Liisi Laineste, Estonian Literary

Museum, Estonia

Sharon Lockyer, Brunel University,

UK 
John Morreall, College of William and Mary, USA

Moira Marsh, Indiana University, USA Alleen P. Nilsen, Arizona State

University, USA

Don L. F. Nilsen, Arizona State

University, USA

Elliott Oring, California State University, USA

René Proyer, Martin Luther University

Halle, Germany

Victor Raskin, Purdue University,

USA

Willibald Ruch, University of Zurich,

Switzerland

Limor Shifman, Hebrew University of

Jerusalem, Israel

Villy Tsakona, National and Kapodistrian

University of Athens, Greece

CONSULTING EDITORS

Goh Abe

Tokushima Bunri University, Japan

Mostafa Abedinifard

University of British Columbia, Canada

Sammy Basu

Willamette University, USA

Ursula Beermann, UMIT Tirol, Austria
Hugo Carretero Dios

University of Granada, Spain

Elisa Gironzetti, University of

Maryland, USA

Sonja Heintz, University of Plymouth,

UK

Holger Kersten, Otto-von-Guericke

University, Magdeburg, Germany

Andrés Mendiburo-Seguel, Universidad

Andrés Bello, Chile

Tristan Miller, Vienna University,

Austria

Patrice Oppliger, Boston University,

USA

Tracey Platt, University of

Wolverhampton, UK

Béatrice Priego-Valverde, Aix-Marseille

University, France

Julia Taylor Rayz, Purdue University,

USA

Graeme Ritchie

University of Aberdeen, UK

Andrea Samson, University of

Fribourg, Switzerland

Till Weingärtner, University College

Cork, Ireland

Julie A. Woodzicka, Washington and

Lee University, USA

Xiao Dong Yue, Capital Normal

University, China

\section{FORMER EDITORS-IN-CHIEF}

Victor Raskin 1988-1999

Lawrence E. Mintz 2000-2002

Salvatore Attardo 2003-2012

Giselinde Kuipers 2012-2015

Thomas E. Ford 2016-2020

HUMOR is the official journal of the International Society of Humor Studies.

For further information, please see the web site: www.humorstudies.org. 
ABSTRACTED/INDEXED IN Baidu Scholar · BDSL Bibliographie der deutschen Sprach- und Literaturwissenschaft · BLL Bibliographie Linguistischer Literatur · Cabell's Whitelist · CNKI Scholar (China National Knowledge Infrastructure) · CNPIEC: cnpLINKer Dimensions EBSCO (relevant databases) · EBSCO Discovery Service · EMCare · ERIH PLUS (European Reference Index for the Humanities and Social Sciences) · Gale/Cengage · Genamics JournalSeek · Google Scholar · IBR (International Bibliography of Reviews of Scholarly Literature in the Humanities and Social Sciences) · IBZ (International Bibliography of Periodical Literature in the Humanities and Social Sciences) $\cdot$ International Bibliography of the Social Sciences (ProQuest) $\cdot$ J-Gate $\cdot$ Journal Citation Reports/Social Sciences Edition · JournalGuide · JournalTOCs · KESLI-NDSL (Korean National Discovery for Science Leaders) · Linguistic Bibliography · Linguistics Abstracts Online · Microsoft Academic · MLA International Bibliography · MyScienceWork · Naver Academic · Naviga (Softweco) - Norwegian Register for Scientific Journals, Series and Publishers · OLC Linguistik · Primo Central (ExLibris) · ProQuest (relevant databases) · PsycINFO · PSYNDEX · Publons · QOAM (Quality Open Access Market) · ReadCube · SCImago (SJR) · SCOPUS · Semantic Scholar · Sherpa/RoMEO · Summon (ProQuest) · TDNet · Ulrich's Periodicals Directory/ulrichsweb · WanFang Data · Web of Science: Arts \&amp; Humanities Citation Index; Current Contents/Arts \&amp; Humanities; Current Contents/Social and Behavioral Sciences; Social Sciences Citation Index · WorldCat (OCLC)

The publisher, together with the authors and editors, has taken great pains to ensure that all information presented in this work reflects the standard of knowledge at the time of publication. Despite careful manuscript preparation and proof correction, errors can nevertheless occur. Authors, editors and publisher disclaim all responsibility for any errors or omissions or liability for the results obtained from use of the information, or parts thereof, contained in this work.

ISSN 0933-1719 • e-ISSN 1613-3722

All information regarding notes for contributors, subscriptions, Open access, back volumes and orders is available online at www.degruyter.com/view/j/humr

RESPONSIBLE EDITOR Christian F. Hempelmann, Department of Literature and Languages, Texas A\&M University-Commerce, 2200 Campbell Street

Commerce, Texas 75428, USA

E-mail: humorjournal@gmail.com

PUBLISHER Walter de Gruyter GmbH, Berlin/Boston, Genthiner Straße 13, 10785 Berlin, Germany

JOURNAL MANAGER Sabine von Wittke-Holweg, De Gruyter, Genthiner Straße 13, 10785 Berlin, Germany, Tel.: +49 (0)30 260 05-334, E-mail: Sabine.von.Wittke@degruyter.com

RESPONSIBLE FOR ADVERTISEMENTS Markus Kügel, De Gruyter, Rosenheimer Str. 143, 81671 München, Germany, Tel.: +49 8976 902-424, E-mail: anzeigen@ degruyter.com

(C) 2021 Walter de Gruyter GmbH, Berlin/Boston

TYPESETTING TNQ Technologies, Chennai, India

PRINTING Franz X. Stückle Druck und Verlag e.K., Ettenheim

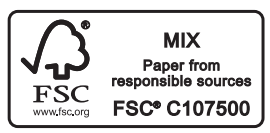




\section{Contents}

\section{Full Length Articles}

David S. Greene and Nancy Dunavant King

Humor and A1C: the interaction between humor and diabetes control -483

Kathryn J Gardner, Nicola-Maria Jabs, Jennifer Drabble and Umair Akram Humor styles influence the perception of depression-related internet memes in depression -497

David Cheng

Self-deprecating humor and task persistence: the moderating role of self-defeating humor style — 519

Paulo A. S. Moreira and Richard A. Inman

Psychometric properties of the Comic Style Markers - Portuguese version: applying bifactor and hierarchical approaches to studying broad versus narrow styles of humor -537

Deniz Arslan, Ugur Sak and Nazmiye Nazli Atesgoz

Are more humorous children more intelligent? A case from Turkish culture -567

\section{Silja Ang-Tschachtli}

The variable of gender and its interplay with mother tongue in the humor and laughter of bilingual couples -589

\section{Béatrice Priego-Valverde}

Failed humor in conversation: disalignment and (dis)affiliation as a type of interactional failure -613

Dieter Declercq and Chihab El Khachab

Satire as safety valve: moving beyond a mistaken metaphor — 637

Adrian Hale

'Do Mormons think The Book of Mormon is funny?' — 659 
Charles Lam

Identities are no joke (or are they?): humor and identity in Vivek Mahbubani's stand-up -679

\section{Book Reviews}

Anastasiya Astapova

Waterlow, Jonathan: It's Only a Joke, Comrade! Humour, Trust and Everyday Life under Stalin — see www.degruyter.com

Patrice A. Oppliger

William V. Costanzo: When the World Laughs: Film Comedy East and West — see www.degruyter.com

Ian Brodie

Claire Schmidt: If You Don't Laugh You'll Cry: The Occupational Humor of White Wisconsin Prison Workers — see www.degruyter.com 